\title{
Secretion of matrix metalloproteinases by human endometrial cells in vitro
}

\author{
M. Martelli ${ }^{1}$, A. Campana ${ }^{2}$ and P. Bischof ${ }^{I_{*}}$ \\ ${ }^{1}$ Department of Obstetrics and Gynecology, University of Geneva; and ${ }^{2}$ Clinic of Infertility and \\ Gynecologic Endocrinology, Geneva, Switzerland
}

\begin{abstract}
At each menstrual cycle, the uterine endometrium undergoes intense remodelling. Of the many factors implicated in tissue remodelling, the matrix metalloproteinases (MMPs) play a central role owing to their capacity to degrade the extracellular matrix. The aim of this study was to examine the nature and cellular origin of endometrial proteases as evaluated in culture systems with clearly characterized cell types. Endometrial cells from hysterectomy specimens were prepared using collagenase digestion. Bone-marrow-derived cells (a known source of proteases) were removed by immunopurification. Cells were cultured on different substrates (matrigel, agarose, glass or plastic). Purity of cell preparations was examined by immunocytochemistry, and proteases were characterized by zymography on SDS-PAGE containing gelatin. The cell phenotype in culture was largely influenced by the type of substrate. Gelatindegrading enzymes detected in culture supernatants of stromal and epithelial cells had molecular masses ranging from 42 to $248 \mathrm{kDa}$, and were identified as metalloproteinases. We conclude that human endometrial stromal and epithelial cells express several matrix metalloproteinases, the expression of which clearly depended on the purity of cell preparation, on cell adhesion and on the nature of the substrate on which the cells grew. These enzymes might be involved in endometrium remodelling, blastocyst implantation and trophoblast invasion.
\end{abstract}

\section{Introduction}

The uterine endometrium, a well-known target for steroid hormones, is regularly shed and rebuilt throughout reproductive life, implying an active and continuous tissue remodelling. Uterine endometrial cells therefore provide an effective model for studying the role of enzymes implicated in extracellular matrix (ECM) degradation. A wide variety of factors participate in tissue remodelling including growth factors, cytokines and matrix metalloproteinases (MMPs or matrixins). MMPs are a group of highly homologous proteolytic enzymes believed to play a major role in the remodelling of connective tissues under various physiological and pathological conditions (Masure and Opotenakke, 1989; Woessner 1991). These enzymes participate in the breakdown of the major protein components of the extracellular matrix such as collagen, proteoglycans, fibronectin and laminin (Emonard and Grimaud, 1990; Van Wart and Mookhtiar, 1990). These enzymes depend on $\mathrm{Ca}^{2+}$ and $\mathrm{Mg}^{2+}$ and are optimally active at neutral $\mathrm{pH}$ (Birkedal-Hansen, 1988).

Seven MMPs have been identified in mammalian cells (Woessner, 1991) and are grouped in three different classes, depending on their structural homology and substrate specificity, interstitial collagenases, gelatinases and stromelysins. The fibroblast-type interstitial collagenase (MMP-1) (Stricklin et al., 1977; Goldberg et al., 1986) and the neutrophil-type homologue (MMP-8) (Hasty et al., 1990; Mallya et al., 1990; Mookhtiar and Van Wart, 1990) can degrade collagen type I, II

*Reprint requests.

Received 6 April 1992. and III. They are secreted as proenzymes $(52 \mathrm{kDa})$ and are activated by trypsin, plasmin, kallikrein and chymotrypsin in vitro. The $72 \mathrm{kDa}$ gelatinase (MMP-2) produced by proliferating fibroblasts (Sato et al., 1985; Hibbs et al., 1987; Wilhelm et al., 1989) and by tumour cells (Sato et al., 1983; Collier et al., 1988), and the $92 \mathrm{kDa}$ gelatinase (MMP-9) produced by neutrophils (Hibbs and Bainton, 1989), macrophages (Hibbs et al., 1987) and by certain transformed cells (Wilhelm et al., 1989; Bernhard et al., 1990) have an identical substrate specificity degrading native collagen type IV, V and X (Wilhelm et al., 1989; Okada et al., 1990). These gelatinases contain a fibronectin-like domain which allows them to bind to gelatin (denatured type I collagen). The $72 \mathrm{kDa}$ gelatinase is activated by organomercurial salts in vitro and not by plasmin or trypsin. Human fibroblasts also produce stromelysins (Okada et al., 1986; Whitham et al., 1986; Wilhelm et al., 1987; Saus et al., 1988), a group of three homologous enzymes (MMP-3, MMP-10 and MMP-7), that are also called proteoglycanases. These degrade type IV and IX collagens, laminin, fibronectin, elastin and proteoglycans (Chin et al., 1985; Okada et al., 1986, 1989). All MMPs are secreted as inactive proenzymes that are activated by limited proteolysis (He et al., 1989; Okada and Nikanishi, 1989) by other proteases, losing a $10 \mathrm{kDa}$ peptide upon activation. In the active form, MMPs are regulated by inhibitors present in plasma and in the extracellular matrix. MMPs can be inhibited by $\alpha_{2}$-macroglobulin (Barret and Starkey, 1973) and $\alpha_{1}$-antitrypsin present in plasma and by tissue inhibitor of metalloproteinases (TIMP) located in the extracellular space (Cawston et al., 1981). The purification and isolation of TIMP has previously been described (Finn, 1986; Goldberg et al., 1989). 
To our knowledge no MMPs have previously been described in the human endometrium. The present study reports the presence, nature and cellular origin of MMPs in human endometrial cell cultures. Cultures were prepared from hysterectomy specimens. In addition, epithelial and stromal cells were cultured separately on different substrates to investigate the role of cell adhesion on the induction of protease secretion.

\section{Materials and Methods}

\section{Preparation of endometrial cells}

Endometrial tissue was obtained from hysterectomies performed for reasons other than malignancy. The phase of the endometrial cycle was determined on histological sections of the same endometrium. The nine endometria analysed were of the proliferative phase. Furthermore, in three cases, stromal and epithelial cells were obtained from early secretory endometrium bearing a Gravigard intrauterine device (IUD).

All manipulations were performed under sterile conditions. The cell preparation and separation techniques used were adapted from Tseng and Liu (1981) and were based on the fact that collagenase disrupts the stromal cells, leaving the endometrial glands intact. The tissue was minced and washed in Hank's balanced salt solution (HBSS, Sigma, St Louis), containing $200 \mathrm{U}$ penicillin $\mathrm{G} \mathrm{ml}^{-1}\left(10^{6} \mathrm{iu}\right), 200 \mu \mathrm{g}$ streptomycin $\mathrm{ml}^{-1}$ (Hoechst, Darmstadt) and $2.5 \mu \mathrm{g}$ Fungizone $\mathrm{ml}^{-1}$ (Gibco, Basel). The washed tissue was then incubated three times for $20 \mathrm{~min}$ without shaking in a water-bath at $37^{\circ} \mathrm{C}$, in complete medium: RPMI 1640 (Gibco) supplemented with $10 \%$ fetal calf serum (FCS; Amimed, Birsfelden), penicillin G ( $\left.10^{6} \mathrm{iu}\right), 200 \mu \mathrm{g}$ streptomycin $\mathrm{ml}^{-1}, 2.5 \mu \mathrm{g}$ Fungizone $\mathrm{ml}^{-1}$, to which $1 \mathrm{mg}$ collagenase $\mathrm{ml}^{-1}\left(0.287 \mathrm{U} \mathrm{ml}^{-1}\right.$ from Clostridium histolyticum; Boehringer, Mannheim GmbH, Germany) was added. After each step, the collagenase digestion was stopped by the addition of complete medium to the supernatant.

The supernatants consisting of stromal cells (the endometrial glands sedimented rapidly) were pooled, centrifuged at $700 \mathrm{~g}$ for $5 \mathrm{~min}$, and the cells resuspended in culture medium consisting of complete medium in which the $10 \%$ FCS was heat inactivated $\left(56^{\circ} \mathrm{C}\right.$ for $\left.30 \mathrm{~min}\right)$ and acid treated adjusted to $\mathrm{pH} 3$ with $1 \mathrm{~mol} \mathrm{HCl} l^{-1}$, for $2 \mathrm{~h}$ at room temperature and neutralized with $1 \mathrm{~mol} \mathrm{NaOH} \mathrm{l^{-1 }}$. Cells were counted in a Neubauer cell in the presence of Trypan blue $0.5 \%$ Trypan blue, Serva, Feinbiochemica, Heidelberg, in normal saline $0.9 \% \mathrm{NaCl}$ ): half of the cells were placed in culture immediately and the other half were further immunopurified.

The remaining sedimented glands were incubated with shaking at $37^{\circ} \mathrm{C}$ for $2 \mathrm{~h}$, in complete medium with $300 \mathrm{mg}$ collagenase $\mathrm{ml}^{-1}\left(330 \mathrm{U} \mathrm{ml} l^{-1}\right.$ from Clostridium histolyticum, Sigma, St Louis). After addition of complete medium, the tubes were centrifuged and the supernatant discarded. The pellet consisting of endometrial glands was cultured for $5-7$ days at $37^{\circ} \mathrm{C}$ in complete medium. Once a monolayer of epithelial cells was obtained, the culture was trypsinized (trypsin (1:250) $0.05 \%$, EDTA $0.02 \%$, Boehringer Mannheim $\mathrm{GmbH}$, Germany) washed with complete medium and the cells counted in the presence of Trypan blue. Half of the cells were put into culture and the other half was immunopurified.

\section{Immunopurification of endometrial cells}

Cell suspensions were incubated with $50 \mu \mathrm{l}$ of a mouse monoclonal antibody against human leucocyte common antigen (anti-LCA, anti-CD45, Dakopatts, Copenhagen) for $30 \mathrm{~min}$ at $4^{\circ} \mathrm{C}$ and shaken occasionally. After incubation, cells were washed with PBS containing: $137 \mathrm{mmol} \mathrm{NaCl}{ }^{-1}, 3 \mathrm{mmol} \mathrm{KCl}$ $\mathrm{l}^{-1}, 8 \mathrm{mmol} \mathrm{Na} \mathrm{HPO}_{4} \mathrm{l}^{-1}, 1.5 \mathrm{mmol} \mathrm{KH}_{2} \mathrm{PO}_{4} \mathrm{l}^{-1}$ at $\mathrm{pH} 7.4$ supplemented with $0.1 \%$ BSA (RIA grade, Sigma, St Louis). Prewashed (PBS-BSA 0.1\%), magnetic particles $(50 \mu \mathrm{l})$ coated with a second antibody, sheep anti-mouse IgG (Dynabeads $M$ 280, Dynal, Milan Analytica, Switzerland), were then added to the cell suspension and incubated for $20 \mathrm{~min}$ at $4^{\circ} \mathrm{C}$. A magnet was applied along the test tube to retain the particles bound to the cells expressing LCA. The supernatant was poured into a clean tube and the cells were washed with complete medium and counted.

\section{Cell culture}

One million epithelial or stromal cells per $\mathrm{ml}$ were routinely incubated in culture medium in a 12 -well tissue culture plate (Costar, Cambridge, USA) and kept at $37^{\circ} \mathrm{C}$ under a $5 \% \mathrm{CO}_{2}$ atmosphere in air. Wells were either uncoated or precoated with basement membrane-like material (matrigel $300 \mu \mathrm{l}$ per well: Collaborative Research, Inotech, Switzerland), agarose (300 $\mu \mathrm{l}$ per well: $0.5 \%$ in PBS, Agar Noble, Difco, Detroit) or glass (cover slips, Gribi AG, Bern). Medium was replaced every two days, centrifuged at $700 \mathrm{~g}$ and the unattached cells (if any) returned to their original well. Aliquots of the supernatants were immediately frozen at $-20^{\circ} \mathrm{C}$.

\section{Zymography}

Zymography was performed according to Fisher et al. (1989) with some modifications. Gelatin (Merck, Darmstadt) at a final concentration of $1 \mathrm{mg} \mathrm{ml}^{-1}$ was incorporated into the running gel containing $10 \%$ acrylamide (Fluka AG, Buchs, Switzerland), $25 \% \quad 1.5 \mathrm{~mol}$ Tris(hydroxymethyl)-aminomethane $\mathrm{l}^{-1}$ (Tris buffer, Merck, Darmstadt) pH 8.8, 0.4\% SDS (Merck), $0.3 \%$ ammonium peroxodisulfate (APS; Merck). A stacking gel was layered containing $2 \%$ acrylamide, $0.05 \% N, N^{\prime}$-methylene-bisacrylamide, $25 \%$ Tris buffer (Tris $0.5 \mathrm{~mol} \mathrm{l}^{-1}, \mathrm{pH} 6.5,0.4 \%$ SDS), $0.4 \%$ APS and $0.1 \%$ N,N,N,N-tetramethylethylendiamine (TEMED).

The dimensions of the gel were $80 \times 85 \times 0.8 \mathrm{~mm}$. Sample buffer $(5 \mu \mathrm{l})$ consisting of $17.4 \%$ SDS, $7 \%$ sucrose (Fluka AG, Buchs) and $10 \mu \mathrm{l}$ bromophenol in water (Siegfried, Zofingen) was added to $30 \mu \mathrm{l}$ of the standardized $\left(10^{6}\right.$ cells $\mathrm{ml}^{-1}$ ) cell supernatants to be analysed and $25 \mu \mathrm{l}$ of this mixture applied to the gel. Electrophoresis ran for approximately $4 \mathrm{~h}$ at 7 mamp at $5-7^{\circ} \mathrm{C}$ in $25 \mathrm{mmol}$ Tris $-\mathrm{HCl} \mathrm{l}^{-1}$ containing $0.19 \mathrm{~mol}$ glycine $\mathrm{l}^{-1}$ and $0.1 \%$ SDS, $\mathrm{pH}$ 8.6. After electrophoresis, the gel was washed six times for $5 \mathrm{~min}$ at room temperature on a moving platform in $2.5 \%$ Triton X-100 in water (Sigma), and three times in PBS. The gel was then incubated overnight at room temperature in PBS, $\mathrm{pH} 7.4$, containing $\mathrm{CaCl}_{2}\left(0.9 \mathrm{mmol} \mathrm{l}^{-1}\right)$ and $\mathrm{MgCl}_{2}$ $\left(0.5 \mathrm{mmol} \mathrm{l}^{-1}\right)$, or $\operatorname{EDTA}\left(1,5,10\right.$ or $20 \mathrm{mmol} \mathrm{l}^{-1}$; Fluka $\left.\mathrm{AG}\right)$, 1,10-phenanthroline $\left(0.2\right.$ or $\left.2 \mathrm{mmol}^{-1}\right)$, 1 mmol iodoacetamide 
Table 1. Immunocytochemistry of human endometrial cells in culture

\begin{tabular}{|c|c|c|c|c|c|}
\hline \multirow[b]{2}{*}{$\begin{array}{l}\text { Antibody } \\
\text { used }\end{array}$} & \multirow[b]{2}{*}{ Cell detected } & \multicolumn{2}{|c|}{ Supernatant } & \multicolumn{2}{|c|}{ Pellet $^{\mathrm{a}}$} \\
\hline & & $\begin{array}{c}\text { Before } \\
\text { purification } \\
(\%)\end{array}$ & $\begin{array}{c}\text { After } \\
\text { purification } \\
(\%)\end{array}$ & $\begin{array}{c}\text { Before } \\
\text { purification } \\
(\%)\end{array}$ & $\begin{array}{c}\text { After } \\
\text { purification } \\
(\%)\end{array}$ \\
\hline Keratin & Epithelial & $2.6 \pm 2.1$ & $2.5 \pm 0.7$ & $70 \pm 18.3$ & $76.7 \pm 11.2$ \\
\hline LCA & Bone-marrow-derived cells & $20.4 \pm 5.2$ & $0.2 \pm 0.4$ & $2.5 \pm 2.1$ & $0.5 \pm 0.7$ \\
\hline Factor VIII & Endothelial & $1.4 \pm 0.9$ & $0.8 \pm 0.8$ & $2 \pm 0$ & $0.5 \pm 0.5$ \\
\hline Vimentin & $\begin{array}{l}\text { Stromal bone-marrow-derived } \\
\text { cells endothelial }\end{array}$ & $93.6 \pm 10.1$ & $98 \pm 2.64$ & $12.5 \pm 8.5$ & $3.5 \pm 0.7$ \\
\hline
\end{tabular}

Values given are means $\pm \mathrm{SD}, n=9$ from proliferative phase and $n=3$ secretory phase bearing a Gravigard intrauterine device.

'Immunohistochemistry performed after trypsinization of endometrial monolayers obtained from intact glands grown in vitro for 5-6 days.

'Stromal or epithelial cell purification with Dynabeads and LCA monoclonal antibody.

LCA: Leucocyte Common Antigen (CD45).

$1^{-1}$ or $1 \mu \mathrm{mol}$ pepstatine $\mathrm{l}^{-1}$ (all from Sigma). After incubation, the gels were stained with Coomassie brilliant blue $\mathrm{G} 250$ (Fluka AG, $0.1 \%$ in $25 \%$ methanol and $10 \%$ acetic acid in water) for $1 \mathrm{~h}$, and destained in $5 \%$ methanol with $7.5 \%$ acetic acid in water. Proteolytic activity appeared as clear bands on a blue background. An electrophoresis calibration kit containing protein standards (Pharmacia, Uppsala) for molecular mass determination were run on each gel. The kit provided five protein standards covering the molecular mass range from 53 to $212 \mathrm{kDa}$. The distance of migration of the digestion bands was compared with that of the standards (log molecular mass versus distance of migration in $\mathrm{mm}$ ) to determine their size.

\section{Immunocytochemistry}

Before culture, aliquots of the different cell suspensions were centrifuged onto microscope slides in a cytocentrifuge. The slides were fixed in acetone at $-20^{\circ} \mathrm{C}$ for $5 \mathrm{~min}$, then washed twice with PBS. The following manipulations were performed at room temperature. PBS-BSA, $5 \%(5 \mu \mathrm{l})$, was added on the cells, and after $10 \mathrm{~min}$ the liquid was gently blotted and replaced with $50 \mu \mathrm{l}$ of the first antibody (monoclonal mouse anti-human: LCA, Factor VIII, Vimentin, all from Dakopatts, Copenhagen, anticytokeratine, clones AE1/AE3 from Boehringer, Mannheim, and anticytokeratin CAM 5.2 from Becton Dickinson, Inotech, Switzerland), these last two antibodies were used as a mixture (1:1). After $30 \mathrm{~min}$, the glass slides were washed twice with PBS and the cells incubated with a second antibody bound to alkaline phosphatase $(50 \mu \mathrm{lgG}$ rabbit anti-mouse, Dakopatts). After incubation and washing, the second antibody was replaced by a third antibody: swine anti-rabbit IgG coupled to alkaline phosphatase ( $50 \mu \mathrm{l}$, Dakopatts) and incubated as above. Slides were then washed and incubated for $5 \mathrm{~min}$ with $5 \mathrm{mg}$

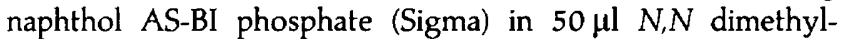
formamide containing $10 \mathrm{mg}$ fast red TR salt (Sigma) and $10 \mathrm{mg}$ of levamisolhydrochloride (Sigma) in $0.1 \mathrm{~mol}$ Tris- $\mathrm{HCl} \mathrm{I}^{-1}$ pH 8.2. After washing, the slides were counterstained with haematoxylin and evaluated under the microscope. The results were expressed in per cent as the number of positive cells per 300 total cells counted.

\section{Results}

\section{Immunocytochemistry}

The sedimentation technique used to separate stromal and epithelial cells from hysterectomy specimens was highly efficient (see Table 1). The supernatant contained between 80 and $100 \%$ stromal cells, whereas the pellet was rich in epithelial cells $(\mathbf{7 7 \%})$. The major contaminant of the epithelial cell preparation was the stromal cells. After immunopurification the majority (more than 95\%) of bone-barrow-derived cells were removed.

\section{Phenotype of cells in culture}

Stromal cells. Within $24 \mathrm{~h}$ of culture, proliferative endometrial stromal cells adhered to matrigel, glass and plastic, but not to agarose. The cells flattened out on the matrices, and grew into small colonies of aggregated cells. On glass and plastic, cells formed a monolayer (Fig. Ic, d, e and f), whereas on matrigel no monolayer was seen (Fig. 1a, c). On agarose, cells remained viable (negative with Trypan blue); however, they floated in the medium where they grew as aggregates (Fig. 1g, h). With time, these aggregates increased in size with no evidence of attachment. Irrespective of the substrate on which the stromal cells were grown, immunopurified cells grew in much larger colonies. This was particularly evident on matrigel where at day 9 the colonies of immunopurified cells were five times larger than the colonies of normal stromal cells (Fig. 1a, b).

Epithelial cells. After collagenase digestion, the glands remained intact. Glands from proliferative endometrium were shorter, thinner and less tortuous than those obtained during the secretory phase (Gravigard IUD bearing uteri). After 5 to 7 days, the glands were no longer recognizable and the epithelial cells formed a monolayer; these were then trypsinized and grown on different substrates.

Within $24 \mathrm{~h}$ of culture, epithelial cells adhered to matrigel (Fig. 2a, b) and formed a pattern consisting of epithelial cells 
(a)
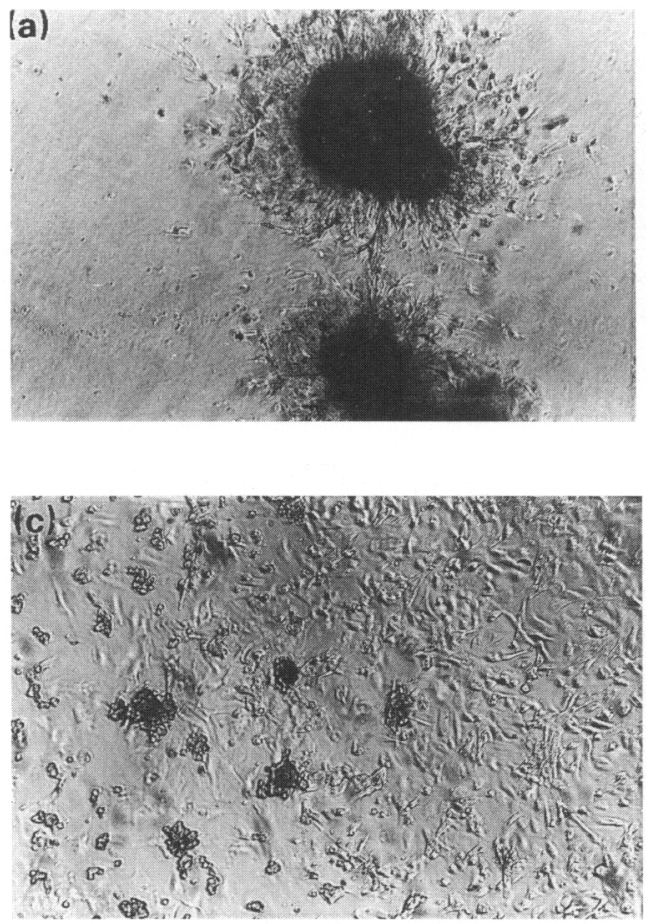
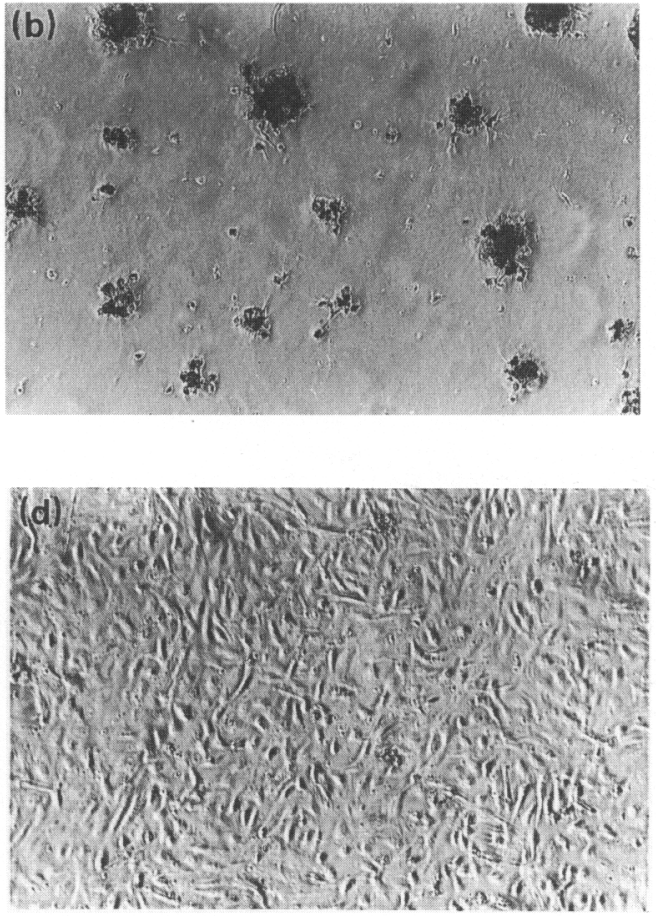
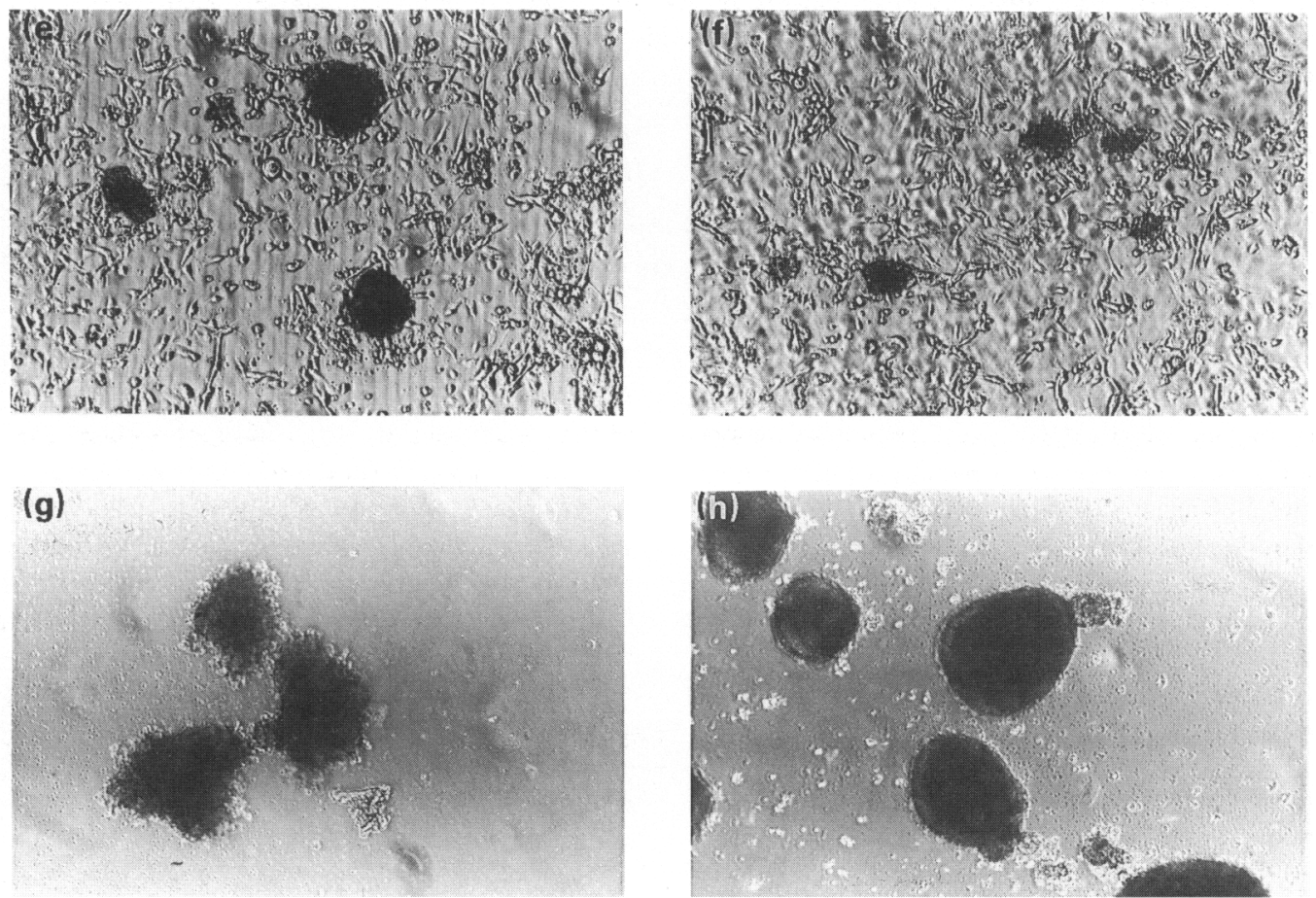

Fig. 1. Conventional microscopy of endometrial stromal cells obtained from a proliferative endometrium at 9 days of culture. Immunopurified ( $a, c, e, g)$ or non-immunopurified (b, d, f, h) cells were grown on matrigel $(a, b)$; glass $(c, d)$; plastic $(e, f)$ and agarose $(g, h)$. Scale bar $=100 \mu \mathrm{m}$. 

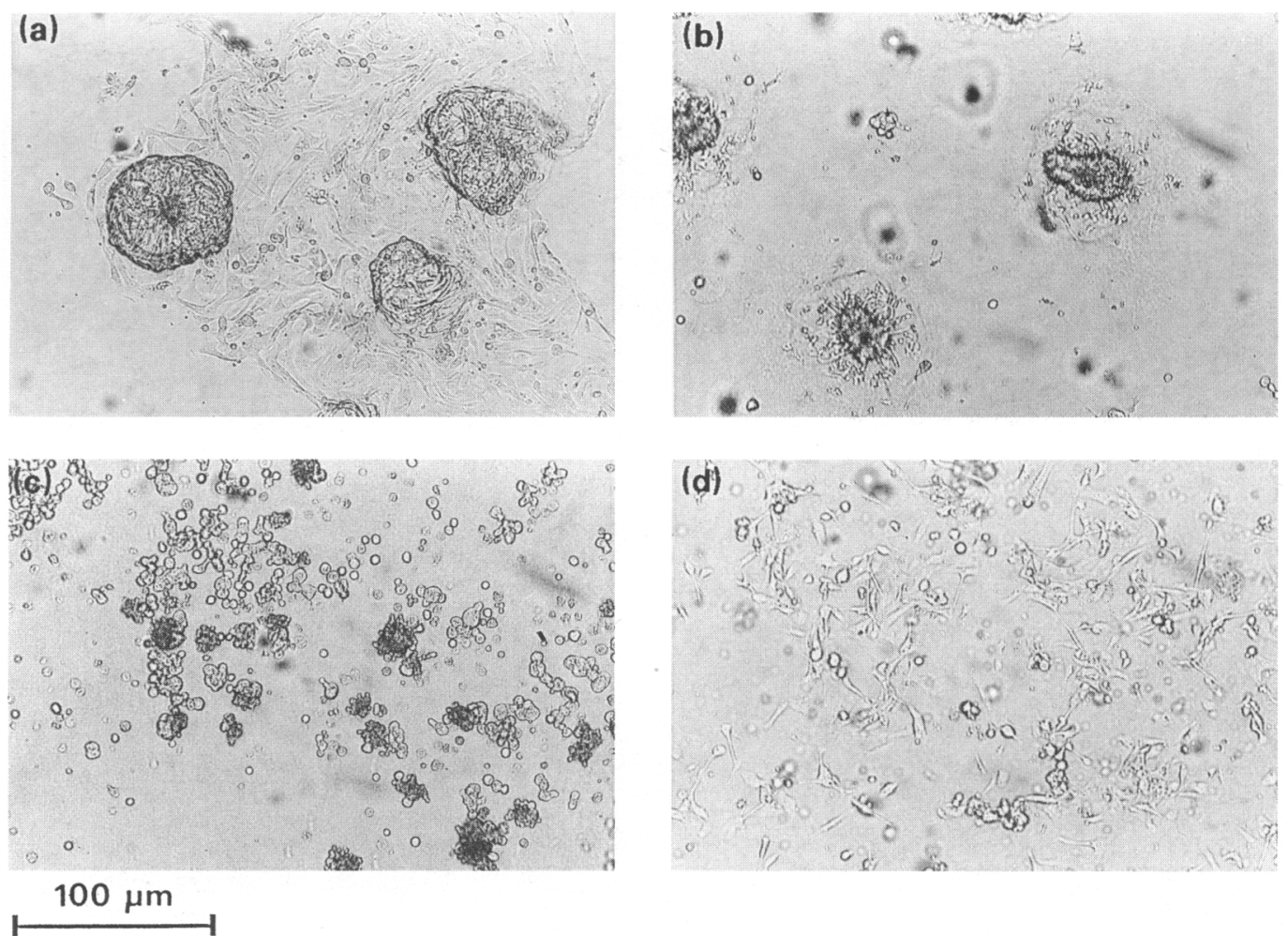

Fig. 2. Conventional microscopy of endometrial epithelial cells obtained from a proliferative endometrium at 9 days of culture. Immunopurified $(a, c)$ or non-immunopurified $(b, d)$ cells were grown on matrigel $(a, b)$ and agarose (c, d). Scale bar $=100 \mu \mathrm{m}$.

surrounding an empty space, resembling a glandular lumen. Immunopurified epithelial cells (Fig. 2a) grew into larger glandular-like structures than normal epithelial cells. After 9 days, the glandular-like structures formed by immunopurified cells were about twice the size of those formed by normal cells (Fig. 2a, b). On agarose (Fig. 2c, d), cells remained viable and floating in the medium during prolonged culture. Aggregates of cells were seen only if the epithelial cells had been immunopurified (Fig. 2a, c). Minimal aggregation occurred in non-purified epithelial cell cultures on agarose. The phenotypes of the cells obtained from proliferative and secretory phase (Gravigard IUD bearing) endometrium were similar. The viability of endometrial cells grown on different matrices was the same at all incubation times, as analysed with Trypan blue.

\section{Protease release}

Conditioned medium of proliferative endometrial cells was analysed by zymography on polyacrylamide-gelatin gel electrophoresis. After $48 \mathrm{~h}$ of culture, stromal cell supernatants expressed four to eight digestion bands with molecular masses ranging from 42 to $248 \mathrm{kDa}$ (Fig. 3). Four gelatinase bands were present on zymograms of immunopurified stromal cell supernatants (Fig. 3a, b and c; Table 2), whereas six to eight bands were seen with non-immunopurified cell supernatants (Fig. 3d, e and $\mathrm{f}$ ). Two of these bands ( 89 and $64-58 \mathrm{kDa}$ ) appeared to be more intense than the others which had molecular masses of $113,105,82$ and $53 \mathrm{kDa}$. The number of gelatinases with molecular masses below $53 \mathrm{kDa}(49,46,43$ and $42 \mathrm{kDa})$ ranged from two to four (Fig. 3). In the supernatants from purified endometrial epithelial cells after $48 \mathrm{~h}$ (Fig. 4) only two gelatinases were expressed (three gelatinases in non-immunopurified epithelial cell preparation), both of which had the same molecular mass as the most intense bands of the stromal cell supernatant ( 89 and $64 \mathrm{kDa}$ ). Culture medium that had not been exposed to cells was always negative during the zymography.

Effect of duration of culture. Gelatinases were analysed at day 2,5 and 8 of culture. In stromal cell supernatants, the intensity of the gelatinases of higher molecular mass $(248,113,105$ and $89 \mathrm{kDa}$ ) reduced as duration of culture increases. The intensity of the $82 \mathrm{kDa}$ gelatinase changed according to the substrate on which the cells were grown, as well as the incubation time, whereas the intensity of the $64-58 \mathrm{kDa}$ gelatinase increased during incubation (Fig. $3 a-c$ and $d-f$, respectively). For proteases of lower molecular mass $(<53 \mathrm{kDa})$, the duration of incubation did not appear to affect their intensity. Except for a general decrease in intensity of all bands at day 5 of culture, no specific effect could be seen on the intensity of epithelial cell gelatinases (Fig. 4).

Effect of purification. The 248 and $82 \mathrm{kDa}$ gelatinases of stromal cell preparations were clearly of lymphomyeloid origin since after immunopurification these bands could no longer be seen (Fig. $3 a-c$ and $d-f$, respectively). When LCA-positive cells obtained from stromal cell preparation were cultured alone, they released only two gelatinases of 248 and $82 \mathrm{kDa}$, whereas cell-free medium incubated on the same substrates released no detectable proteases (results not shown).

Immunopurification reduced the intensity of the 113, 105 and $89 \mathrm{kDa}$ bands indicating that were of stromal and lymphomyeloid origin. The $64-58 \mathrm{kDa}$ gelatinase was always present 

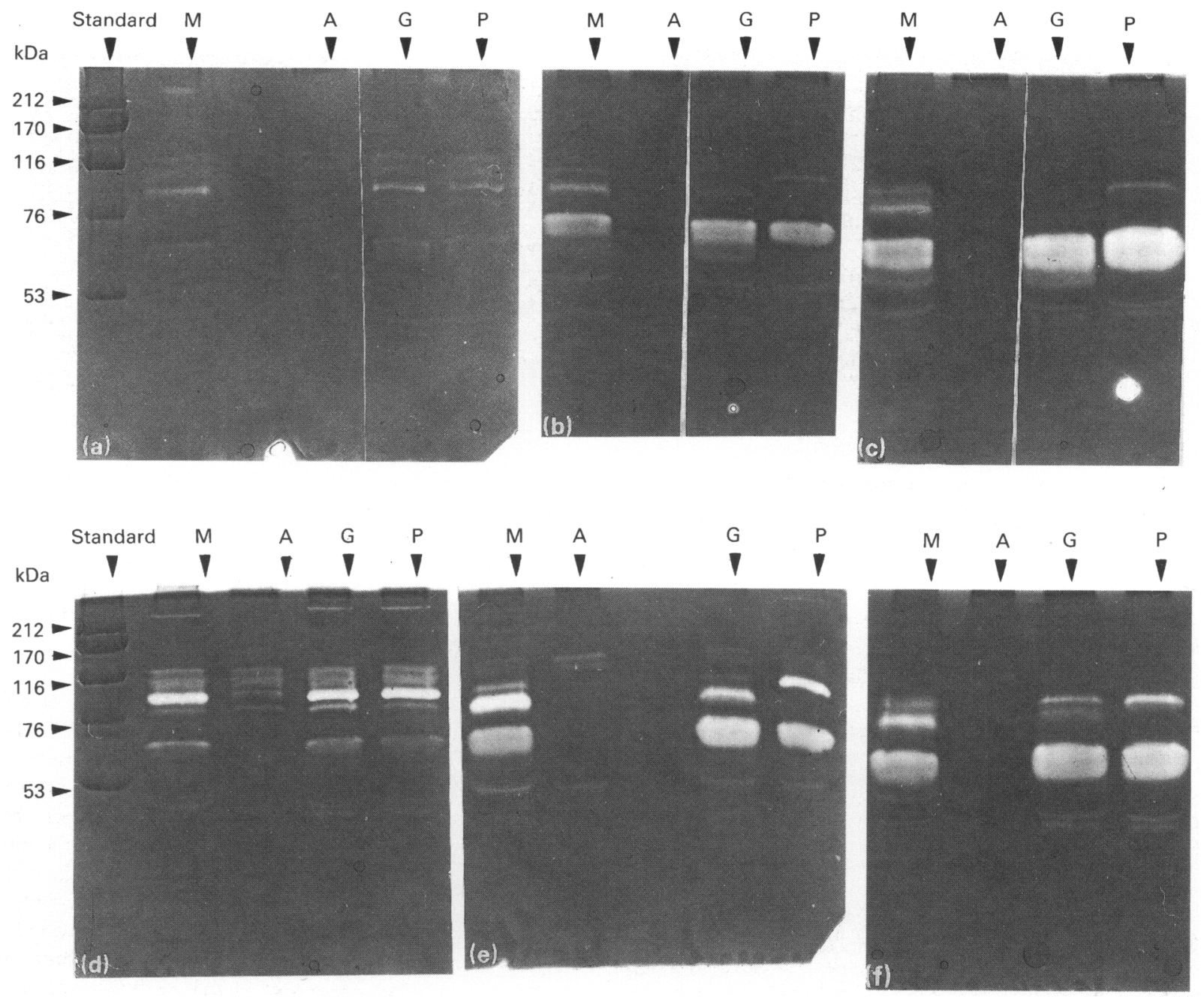

Fig. 3. Zymograms of immunopurified $(a, b, c)$ and non-immunopurified ( $d, e, f)$ stromal cell supernatants from a proliferative endometrium grown on M: matrigel; A: agarose; G: glass; and P: plastic for 0 to 2 days (a, d); 2 to 5 days (b, e) and 5 to 8 days (c, f).

Table 2. Comparison of metalloproteinases in different cell types

\begin{tabular}{|c|c|c|c|c|c|c|c|c|c|}
\hline \multirow[b]{2}{*}{ Cell type } & \multicolumn{8}{|c|}{ Molecular mass ( $\mathrm{kDa}$ ) } & \multirow[b]{2}{*}{ References } \\
\hline & 248 & 197 & 113 & 105 & 89 & 82 & $64-58$ & 53 & \\
\hline Embryonic cells & - & - & + & - & + & + & - & + & Adler et al., 1990 \\
\hline Rabbit corneal fibroblasts & - & - & - & - & + & - & $t$ & + & Fini and Girard, 1990 \\
\hline Alveolar macrophages & - & - & - & - & + & - & t & - & $\begin{array}{l}\text { Shapiro et al., 1990; } \\
\text { Welgus et al., } 1990\end{array}$ \\
\hline Sertoli cells & - & - & + & - & - & + & - & - & Sang et al., 1990 \\
\hline Stromal cells & + & - & + & + & + & + & + & $(+)$ & Bischof et al., 1990 \\
\hline Immunopurified stromal cells & - & - & + & + & + & - & + & $(+)$ & Bischof et al., 1990 \\
\hline Epithelial cells & - & - & - & - & + & + & + & - & Bischof et al., 1990 \\
\hline Immunopurified epithelial cells & - & - & - & - & + & - & + & - & Bischof et al., 1990 \\
\hline Cytotrophoblast cells & + & + & + & + & + & + & + & - & $\begin{array}{l}\text { Bischof et al., 1990; } \\
\text { Fisher et al., } 1989\end{array}$ \\
\hline Immunopurified cytotrophoblast cells & - & + & - & - & + & + & + & - & Bischof et al., 1990 \\
\hline
\end{tabular}




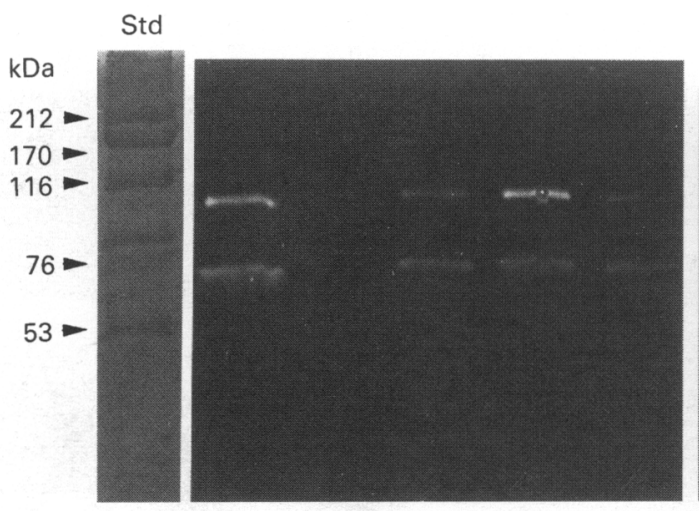

1

2

4

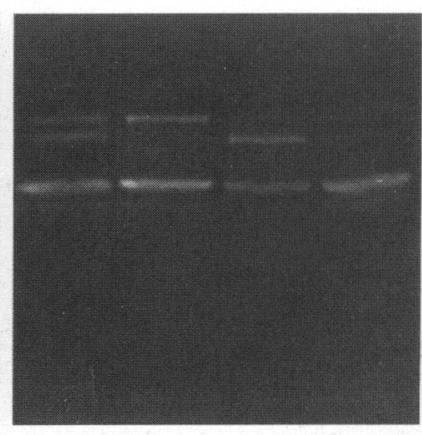

56

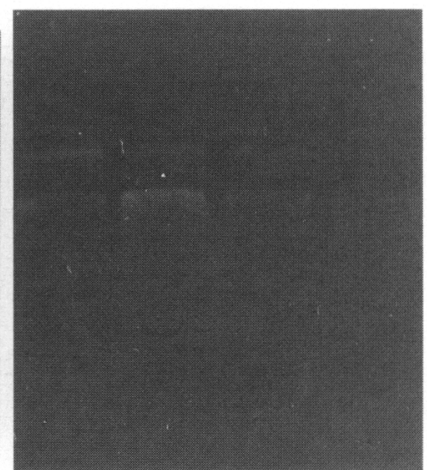

$9 \quad 10 \quad 11$

Fig. 4. Zymograms of immunopurified (lanes 2, 4, 6, 8, 12) and non-immunopurified (lanes 1, 3, 5, 7, 9, 11) epithelial cell supernatants from early proliferative endometrium grown on matrigel (lanes 1, 2, 5, 6, 9, 10) and agarose (lanes 3, 4, 7, 8, 11, 12) for 0 to 2 days (lanes $1-4$ ); 2 to 5 days (lanes $5-8$ ) and 5 to 8 days (lanes 9-12). Std: standard.

with the same intensity irrespective of immunopurification, indicating an exclusively stromal origin of this protease (Fig. 3).

The $82 \mathrm{kDa}$ gelatinase from epithelial cell supernatants was not seen after immunopurification, whereas the intensity of the $89 \mathrm{kDa}$ band was reduced and the $64-58 \mathrm{kDa}$ band remained unchanged (Fig. 4). These results indicate a lymphomyeloid origin for the $82 \mathrm{kDa}$ gelatinase, a dual origin, bone-marrow and epithelial, for the $89 \mathrm{kDa}$ gelatinase and an epithelial origin for the $64-58 \mathrm{kDa}$ gelatinase.

Effect of substrates. The pattern of expression of gelatinases secreted in the supernatant of cells growing on different substrates varied with cell adhesion and the nature of the substrates. Stromal cells grown on agarose did not adhere to this substrate and the gelatinases secreted in the supernatant produced less intense digestion bands than those secreted by cells grown on other substrates (Fig. $3 a-c, d-f$ ). After 2-5 days no digestion band could be seen on the zymogram of the supernatant of cells cultured on agarose indicating a strict adhesion dependence for the expression of the proteases (Fig. $3 a-c$ ). Immunopurified stromal cells grown for more than two days on matrigel strongly expressed the 82 and $89 \mathrm{kDa}$ gelatinases, whereas the same cells grown on plastic expressed only the $89 \mathrm{kDa}$ gelatinase and on glass none of these two bands was seen (Fig. $3 \mathrm{a}-\mathrm{c}$ ). The pattern of expression of the $68-54 \mathrm{kDa}$ gelatinase did not vary with the nature of the substrate, but its expression increased with duration of culture.

Variations during the endometrial cycle. Numerous gelatinases were expressed by stromal cells obtained from secretory endometrium bearing a Gravigard IUD. After immunopurification, only two to six gelatinases was seen (compare Fig. 5a, b). The same digestion bands could be seen when stromal cell supernatants from early or late proliferative endometrium were compared with the previous phase, thus the intensity of the digestion band seemed to vary with phases of the cycle. During the early proliferative phase, the $64-58 \mathrm{kDa}$ gelatinases were more intense than they were later in the cycle. In contrast, the $89 \mathrm{kDa}$ band was apparently more intensely expressed during the proliferative phase than in the early proliferative or early secretory bearing a Gravigard IUD phases (Fig. 5).

Effect of inhibitors and $p H$ changes. The effect of different inhibitors and $\mathrm{pH}$ changes were tested on stromal cell preparations obtained from a proliferative endometrium. When the gels were incubated overnight with 1, 10 phenanthroline $\left(2 \mathrm{mmol}^{-\mathrm{I}}\right.$ ), no digestion bands were visible. When the phenanthroline was replaced by EDTA $\left(20 \mathrm{mmol} \mathrm{I}^{-1}\right)$ the intensity of the digestion bands was drastically reduced. No inhibition was observed with pepstatine $A\left(1 \mu \mathrm{mol} 1^{-1}\right)$, PMSF $(20 \mathrm{mmol}$ $\mathrm{l}^{-1}$ ) or iodoacetamide ( $1 \mu \mathrm{mol} \mathrm{l}^{-1}$, results not shown). The endometrial gelatinases observed here were clearly neutral. Their highest activity was seen at $\mathrm{pH} 7.5$ and bands were less intense when the gels were incubated at higher or lower $\mathrm{pH}$ values.

\section{Discussion}

Human endometrial cells isolated by enzymatic digestion and cultured in vitro are known to yield a mixed cell population. The endometrium is composed not only of stromal and epithelial cells (surface and glandular cells), but in the stroma, besides the stromal and endothelial cells of the blood vessels, many different bone-marrow-derived cells have also been identified. These include macrophages (Hunt, 1989), mast cells (Finn, 1986) and large granular lymphocytes (King and Loke, 1990). Different methods have been proposed for separating these endometrial cells from each other before plating (Lindenberg et al., 1984; Kirk et al., 1978; Satyaswaroop et al., 1979).

Before characterizing the proteases secreted by endometrial cells, we chose to develop a technique for eliminating the bonemarrow-derived cells from the endometrial cell suspension because these cells are known to produce proteases in other tissues (Shapiro et al., 1990). Since leucocyte common antigen (LCA or CD45) is expressed on all bone-marrow-derived cells including those of the human decidua (Starkey et al., 1988) and endometrium (King et al., 1989), we used an antibody to this 

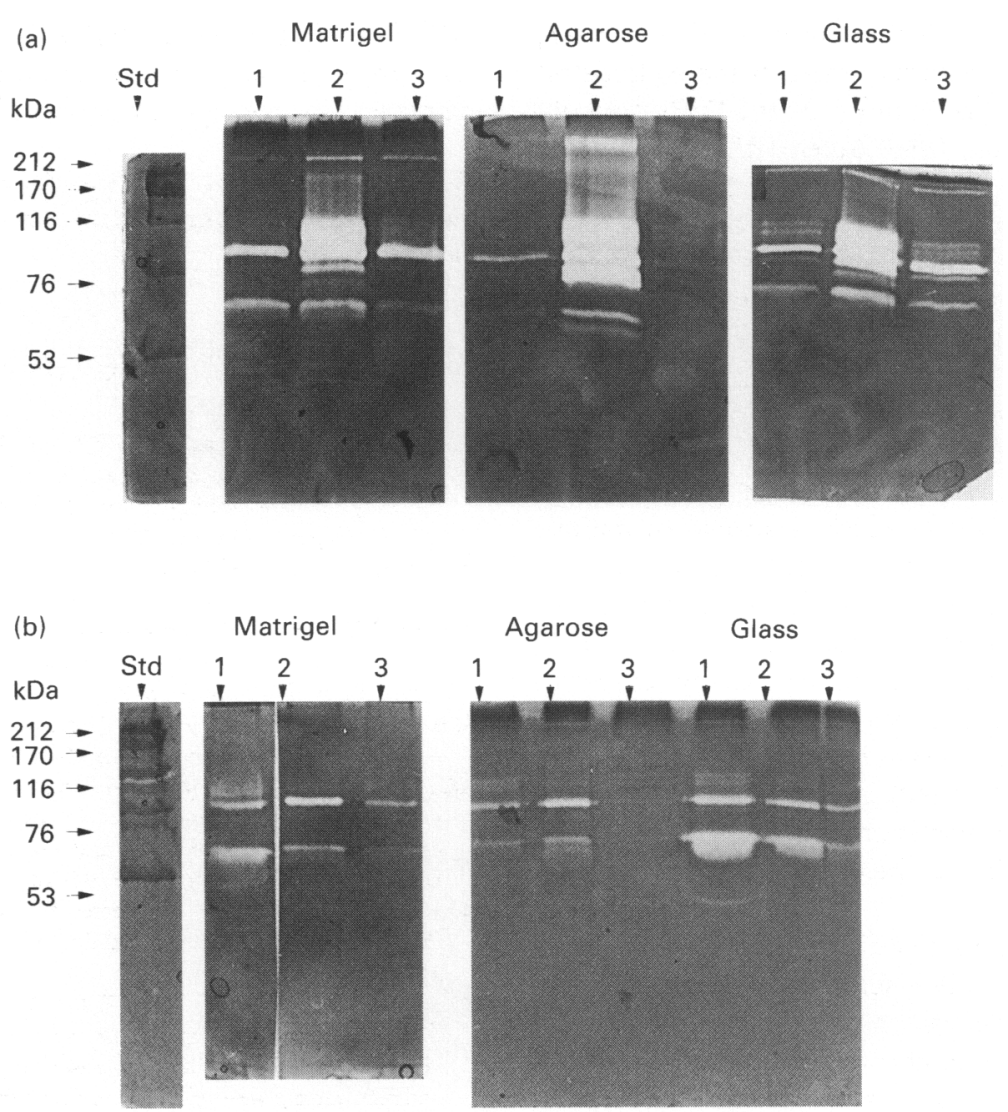

Fig. 5. Zymograms of stromal cell supernatants from endometria obtained at different phases of the menstrual cycle, cultured on matrigel, agarose and glass (days 0-2). (a) Non-immunopurified cells; (b) immunopurified cells; early proliferative endometrium (lane 1); early secretory endometrium bearing a Gravigard IUD (lane 2) and late proliferative endometrium (lane 3).

surface antigen to immunopurify the endometrial cell suspension before plating. This immunopurification procedure was very efficient since very few LCA-positive cells could be seen after immunopurification. This procedure yielded a stromal cell culture of over $95 \%$ purity. The epithelial cell culture however was still contaminated by $3-4 \%$ stromal cells.

As reported previously (Schatz et al., 1990; White et al., 1990), the phenotype of endometrial cells changes with the nature of the substrate on which they grow. Epithelial cells grew into glandular structures when cultured on matrigel (White et al., 1990; the present report) and stromal cells organized themselves into clusters (Schatz et al., 1990; this study). To our knowledge, the study reported here is the first attempt to grow human endometrial cells on agarose on which neither stromal nor epithelial cells attached. The inability of cells to attach to agarose serves as a good control to appreciate the effect of cell attachment on cell growth and protease production. Irrespective of the nature of the substrate on which the cells were cultured, immunopurified stromal or epithelial cells grew into much larger colonies than when bone-marrowderived cells were present in the culture together with the other endometrial cells. This observation indicates that LCA-positive cells produce a factor or factors that inhibit endometrial cell-cell association. If this is also true in vivo, it would attribute to the bone-marrow-derived cell an important paracrine role in the remodelling of the endometrium.

Epithelial and stromal cells in culture expressed gelatinases as shown by zymography. Since serum (including FCS) contains well-known protease inhibitors such as $\alpha_{2}$-macroglobulin and $\alpha_{1}$-antitrypsin, the FCS added to our culture media were heat inactivated and acid treated to denature those inhibitors. This cell-free medium did not have intrinsic gelatinase activity even when incubated for 2 days over matrigel. The observed gelatinases were thus cell specific. These were active at neutral $\mathrm{pH}$ and were inhibited by EDTA or phenanthroline but not by other protease inhibitors, indicating that the observed gelatinases were metalloproteinases. Zymography, as used here, has its limitations which should be kept in mind before discussing the metalloproteinases observed. First, the molecular mass of the digestion bands is an approximation of the true molecular mass of the enzyme because the substrate included in the gel (gelatin) influences the electrophoretic behaviour of the enzymes. Second, SDS has to be used for the electrophoresis to be performed, but since this compound artificially activates the proenzymes into active enzymes, it is not possible to determine whether the metalloproteinases released in the culture medium are activated or not. Finally, the use of gelatin instead of collagen or casein or other substrates limits our observations to 
the gelatinases only. With these limitations in mind, it was very interesting to note that the molecular mass of the endometrial metalloproteinases corresponded to those of the MMPs described in other cell types (Fisher et al., 1989; Adler et al., 1990; Fini and Girard, 1990; Sang et al., 1990; Sato and Mori, 1990; Shapiro et al., 1990; Welgus et al., 1990; Bischof et al., 1991).

Comparison between immunopurified and non-immunopurified endometrial cell cultures showed that the stromal cells released four gelatinases, two of which were also produced by bonemarrow-derived cells $(113,105 \mathrm{kDa})$ : one $(89 \mathrm{kDa})$ was produced by stromal, lymphomyeloid and epithelial cells, whereas the $64-58 \mathrm{kDa}$ band was seen only in purified stromal and epithelial cell supernatants. This last gelatinase corresponds to the $72 \mathrm{kDa}$ collagenase (MMP-2) which is known to migrate with a molecular mass of $66 \mathrm{kDa}$ on gelatin-containing gels when activated (Fini and Girard, 1990). This band was also clearly expressed by cytotrophoblast cells (Bischof et al., 1991). The intensely expressed $89 \mathrm{kDa}$ gelatinase probably represents the $92 \mathrm{kDa}$ collagenase (MMP-2) that degrades collagen type IV and $\mathrm{V}$ and which is also expressed in leucocytes, monocytes, macrophages (Welgus et al., 1990) and cytotrophoblast cells (Bischof et al., 1991). The characterization of these gelatinases will require the use of antibodies before their identity can be assessed.

Before discussing the quantitative changes of MMPs, it must be said that zymography is only a semi-quantitative technique and that the apparent increases or decreases in MMPs on the zymogram might be due to changes in cell number rather than changes in production rates since samples have been standardized according to the number of plated cells.

The expression of the endometrial MMPs seemed to be regulated by cell attachment and by the nature of the matrix on which the cells were grown. In the absence of cell-substrate adhesion (cultures on agarose) the expression of all gelatinases was very weak or absent in comparison to cells grown on glass, plastic or matrigel. Although zymography is only a semiquantitative technique, it seems that the $64-58 \mathrm{kDa}$ gelatinase secreted by stromal but not epithelial cells depends strictly on adhesion, as it was never expresssed by cells grown on agarose. This observation also suggests that there is a cell-specific regulation of the MMPs. The fact that expression of MMPs also depends on the nature of the matrix is illustrated by the fact that stromal cells grown on plastic or glass did not express the $82 \mathrm{kDa}$ gelatinase, whereas this enzyme was strongly expressed when the same cells were grown on matrigel. Besides these in vitro effects on protease activity, ovarian hormones appear to influence metalloproteinase expression. The $64-58 \mathrm{kDa}$ gelatinase appeared to be expressed more during the follicular phase, whereas the $89 \mathrm{kDa}$ gelatinase was more active during the luteal phase of endometrium bearing IUDs. It cannot be ruled out that this effect is due to the IUD rather than to the presence of progesterone at this stage of the cycle. In the cases where an IUD was present, the number and activity of the gelatinases was increased but this was essentially attributable to proteases secreted by bone-marrow-derived cells, as this was no longer after immunopurification.

In conclusion, this study shows for the first time that human endometrial cells release MMPs, the expression of which seems to be regulated by cell attachment and by the nature of substrates as well as other factors. We postulate that endometrial
MMPs are implicated in uterine tissue remodelling after menses or parturition, and in the regulation of blastocyst hatching and implantation as well as trophoblast invasion.

The authors thank L. Haenggeli for her skilful assistance. This work was supported by Swiss National Fund for Scientific Research, grant number 32-29806.90.

\section{References}

Adler RR, Brenner CA and Werb Z (1990) Expression of extracellular matrixdegrading metalloproteinases and metalloproteinase inhibitors is developmentally regulated during endoderm differentiation of embryonal carcinoma cells Development $110211-220$

Barret AJ and Starkey PM (1973) The interaction of alpha-2-macroglobulin with proteinases. Biochemical Journal 133 709-713

Bernhard EJ, Muschel RJ and Hughes EN (1990) Mr. 92,000 gelatinase release contents with the metastatic phenotype in transformed rat embryo cells Cancer Research 50 3872-3877

Birkedal-Hansen H (1988) From tadpole collagenase to a family of matrix metalloproteinases Journal of Oral Pathology 17 445-451

Bischof P, Friedli E, Martelli M and Campana A (1991) Expression of extracellular matrix-degrading metalloproteinases by cultured human cytotrophoblast cells: effects of cells adhesion and immunopurification American Journal of Obstetrics and Gynecology 165 1791-1801

Cawston TE, Galloway WA, Mercer E, Murphy A and Reynolds JJ (1981) Purification of rabbit bone inhibitor of collagenase Biochemical Joumal 195 159-165

Chin JR, Murphy G and Werb Z (1985) Stromelysin, a connective tissuedegrading metalloendopeptidase secreted by stimulated rabbit synovial fibroblasts in parallel with collagenase: biosynthesis, isolation, characterization, and substrates Journal of Biological Chemistry 260 5213-5216

Collier IE, Wilhelm SM, Eisen AZ, Marmer BL, Grant GA, Seltzer JL, Kronberger A, He C, Bauer EA and Goldberg GI (1988) H-ras oncogene-transformed human bronchial epithelial cells (TBE-1) secrete a single metalloproteinase capable of degrading basement membrane collagen Journal of Biological Chemistry $2636579-6587$

Emonard H and Grimaud JA (1990) Matrix metalloproteinases. A review Cellular and Molecular Biology 36 131-153

Fini ME and Girard MT (1990) The pattern of metalloproteinase expression by corneal fibroblasts is altered by passage in cell culture Journal of Cell Science $97373-383$

Finn CA (1986) Implantation, menstruation and inflammation Biology Review 61 312-328

Fisher SJ, Cui T, Zhang L, Hartman L, Grahl K, Guo-Yang Z, Tarpey J and Damsky CH (1989) Adhesive and degradative properties of human placental cytotrophoblast cells in vitro Joumal of Cellular Biology 109 891-902

Goldberg GI, Wilhelm SM, Kronberger A, Bauer EA, Grant GA and Eisen AZ (1986) Human fibroblast collagenase. Complete primary structure and homology to an oncogene transformation-induced rat protein Joumal of Biological Chemistry $2616600-6605$

Goldberg GI, Marmer BL, Grant GA, Eisen AZ, Wilhelm S and He C (1989) Human 72-kilodalton type IV collagenase forms a complex with a tissue inhibitor of metalloproteinase designated TIMP-2 Proceedings of the National Academy of Sciences, USA 86 8207-8211

Hasty KA, Pourmotabbed TF, Goldberg GI, Thompson JP, Spinella DG, Stevens RM and Mainardi CL (1990) Human neutrophil collagenase: a distinct gene product with homology to other matrix metalloproteinases Joumal of Biological Chemistry 265 5647-5659

He C, Wilhem SM, Pentland AP, Marmer BL, Grant GA, Eisen AZ and Goldberg GI (1989) Tissue cooperation in a proteolytic cascade activating human interstitial collagenase Proceedings of the National Academy of Sciences, USA 86 2632-2636

Hibbs MS and Bainton DF (1989) Human neutrophil gelatinase is a component of specific granules Journal of Clinical Investigation 84 1395-1402

Hibbs MS, Hoidal JR and Kang AH (1987) Expression of a metalloproteinase that degrades native type $\mathrm{V}$ collagen and denatured collagens by cultured human alveolar macrophages Joumal of Clinical Investigation 80 1644-1650

Hunt JS (1989) Macrophages in human uteroplacental tissues: a review American Journal of Reproduction and Immunology 21 119-122 
King A and Loke YW (1990) Uterine large granular lymphocytes: a possible role in embryonic implantation? American Joumal of Obstetrics and Gynecology 162, 308-310

King A, Wellings V, Garner L and Loke YW (1989) Immunocytochemical characterization of the unusual large granular lymphocytes in human endometrium throughout the menstrual cycle Human Immunology $\mathbf{2 4}$ 195-205

Kirk D, King RJB and Heyes J (1978) Normal human endometrium in cell culture. I. Separation and characterization of epithelial and stromal component in vitro In Vitro $14651-662$

Lindenberg S, Lauritsen JG, Nielsen MH and Larsen JF (1984) Isolation and culture of human endometrial cells Fertility and Sterility 41 650-652

Mallya SK, Mookhtiar KA, Gai Y, Brewk, Dioszegi M, Birkedal-Hansen $\mathrm{H}$ and VanWart HE (1990) Characterization of 58-Kilodalton human neutrophil collagenase: comparison with human fibroblast collagenase Biochemistry 29 $10628-10634$

Masure S and Opotenakke G (1989) Cytokine-mediated proteolysis in tissue remodelling Experientia 45 542-549

Mookhtiar KA and Van Wart HE (1990) Purification to homogeneity of latent and active 58-Kilodalton forms of human neutrophil collagenase Biochemistry $2910620-10627$

Okada Y and Nakanishi I (1989) Activation of matrix metalloproteinase 3 (stromelysin) and matrix metalloproteinase 2 ("gelatinase") by human neutrophil elastase and cathepsine FEBS Letters 249 353-356

Okada Y, Nagase H and Harris ED, Jr (1986) A metalloproteinase from human rheumatoid synovial fibroblasts that digests connective tissue matrix components: purification and characterization Journal of Biological Chemistry 261 I4 245-14 255

Okada Y, Konomi H, Yada T, Klimata K and Nagase H (1989) Degradation of type IX collagen by matrix metalloproteinase 3 (stromelysin) from human rheumatoid synovial cells FEBS Letters 244 473-476

Okada Y, Morodomi T, Enghild JJ, Suzuki K, Yasui A, Nakanishi I, Salvesen G and Nagase $H$ (1990) Matrix metalloproteinase 2 from human rheumatoid synovial fibroblast European Joumal of Biochemistry 194 721-730

Sang QX, Stetler-Stevenson WG, Liotta LA and Byers SW (1990) Identification of type IV collagenase in rat testicular cell culture: influence of peritubularSertoli cell interactions Biology of Reproduction 43 956-964

Sato T, Liotta LA and Tryggvason K (1983) Purification and characterization of a murine basement membrane collagen-degrading enzyme secreted by metastatic tumor cells Joumal of Biological Chemistry 258 3058-3063

Sato T, Turpeenniemi-Hujanen T and Tryggvason K (1985) Tumor-promoting phorbol esters and cell proliferation stimulate secretion of basement membrane (type IV) collagen-degrading metalloproteinase by human fibroblasts Journal of Biological Chemistry $2608526-8531$

Sato T, Ito A and Mori Y (1990) Interleukin 6 enhances the production of tissue inhibitor of metalloproteases (TIMP) but not that of matrix metalloproteases by human fibroblasts Biochemical and Biophysical Research Communication 170 $824-829$

Satyaswaroop PG, Bressler RS, De la Pena MM and Gurpide E (1979) Isolation and culture of human endometrial glands The Journal of Clinical Endocrinology and Metabolism 48 639-641

Saus J, Quinones S, Otani Y, Nagase H, Harris ED, Jr and Kurkinen M (1988) The complete primary structure of human matrix metalloproteinase-3. Identity with stromelysin Joumal of Biological Chemistry 263 6742-6745

Schatz F, Gordon RE, Laufer N and Gurpide E (1990) Culture of human endometrial cells under polarizing conditions Differentiation 42 184-190

Shapiro DS, Campbell EJ, Kobayashi DL and Welgus HG (1990) Immune modulation of metalloproteinase production in human macrophage: selective pre-translational suppression of interstitial collagenase and stromelysin biosynthesis by gamma interferon Joumal of Clinical Investigation 18 1204-1210

Starkey PM, Sarget IL and Redman CWG (1988) Cell populations in human early pregnancy decidua: characterization and isolation of large granular lymphocytes by flow cytometry Immunology 65 129-134

Stricklin GP, Bauer EA, Jeffrey JJ and Eisen AZ (1977) Human skin collagenase: isolation of precursor and active forms from both fibroblast and organ cultures Biochemistry $16 \quad 1607-1615$

Tseng L and Liu HC (1981) Stimulation of arylsulfotransferase activity by progestins in human endometrium in vitro The Joumal of Clinical Endocrinology and Metabolism 53 418-421

Van Wart HE and Mookhtiar KA (1990) Biological response modifiers for tissue repair, pp. 23-50 Eds G Grotendarst, LM Hjelmeland and JP Gills. Portfolio, The Woodlands, TX

Welgus HG, Campbell EJ, Cura JD, Eisen AZ, Senior RM, Wilhelm SM and Goldberg GI (1990) Neutral metalloproteases produced by human mononuclear phagocytes Joumal of Clinical Investigation 86 1496-1502

White TEK, Di Sant'Agnese PA and Miller RK (1990) Human endometrial cells grown on an extracellular matrix form simple columnar epithelial and glands In Vitro Cellular and Developmental Biology $26636-642$

Whitham SE, Murphy G, Angel P, Rahmsdorf H-J, Smith BJ, Lyons A, Harris TJR, Reynolds JJ, Herrlich P and Docherty AJP (1986) Comparison of human stromelysin and collagenase by cloning and sequence analysis Biochemical Joumal 240 913-916

Wilhelm SM, Collier IE, Kronberger A, Eisen AZ, Marmer BL, Grant GA, Bauer EA and Goldberg GI (1987) Human skin fibroblast stromelysin: structure, glycosylation, substrate specificity and differential expression in normal and tumorigenic cells Proceedings of the National Academy of Sciences, USA $\mathbf{8 4}$ 6725-6729

Wilhelm SM, Collier IE, Marmer BL, Eisen AZ, Grant GA and Goldberg GI (1989) SV40-transformed human lung fibroblasts secrete a 92-kDa type IV collagenase which is identical to that secreted by normal human macrophages Joumal of Biological Chemistry $26417213-17221$

Woessner JF, Jr (1991) Matrix metalloproteinases and their inhibitors in connective tissue remodeling FASEB Journal 5 2145-2154 